\title{
Evaluation of Different Primers for Detection of Brucella by Using PCR Method
}

\author{
Zahra Moulana ${ }^{1}$, Mohammad Reza Hasanjani Roushan², Seyed Mahmoud Amin Marashi ${ }^{3}$
}

\author{
${ }^{1} \mathrm{Ph} . D$. in Biomedical Sciences, Infectious Diseases and Tropical Medicine Research Center, Babol University of \\ Medical Sciences, Babol, Iran \\ ${ }^{2}$ Professor of Infectious Diseases, Infectious Diseases and Tropical Medicine Research Center, Babol University of \\ Medical Sciences, Babol, Iran \\ ${ }^{3}$ Assistant Professor in Medical Bacteriology Department of Microbiology and Immunology Alborz University of \\ medical sciences, Karaj, Iran
}

\section{Type of article: Original}

\begin{abstract}
Introduction: Brucellosis is a worldwide zoonosis and a significant cause of loss of health in humans and animals. Traditionally, classic diagnosis is carried out by isolation of Brucella, which is time-consuming, technically challenging and potentially dangerous. The aim of this study was to expand a molecular test that would be used for the develop detection of Brucella in a single reaction with high sensitivity and specificity, by targeting IS711element.

Methods: This study was carried out from 2015 to 2016 at the Ayatolla Rohani hospital in Babol, Iran. The present study was designed to develop PCR assay, based on IS711 gene for rapid diagnosis of Brucella spp. and immediate detection of Brucella, with high sensitivity and specificity. Four pairs of oligo-nucleotide primers with sizes of 547, 403, 291 and 127bp respectively, were planned to exclusively amplify the targeted genes of Brucella species.

Results: Our results show that, five PCR primers set up, would be helpful in amplifying the DNAs from the genus Brucella with high specificity and sensitivity so it can be $12 \mathrm{fg}$, for Brucella species to provide a valuable tool for diagnosis.

Conclusion: This method can be more useful than serological and biochemical tests and in addition, this reduces the number of required tests more rapidly and economically.

Keywords: Brucellosis, Diagnosis, Polymerase chain reaction, IS711gene
\end{abstract}

\section{Introduction}

Brucella species are facultative intracellular gram-negative bacteria, which is very common worldwide, causing zoonosis infection disease particularly in domestic animals, and is transmittable to humans $(1,2)$ The genus Brucella consist of 10 species which are isolated from animals, but among these species, B. abortus and $B$. melitensis are generally causative agents for humans $(3,4)$. Since the clinical feature of brucellosis has overlap with an extensive range of infectious and non-infectious diseases, the most reliable way to diagnose this infection, is through laboratory methods, although it is not always successful (5). Nowadays, microbiological culture and serological tests are the most common methods for detection of Brucella spp. Although isolation of the bacteria is the "gold standard", microbial culture is often negative and dependent on the culture medium, quantity of circulating bacteria and Brucella species (6). Therefore serological tests such as Standard Serum Agglutination test (SAT) seem to be more effective for diagnosis, although, sometimes there can be cross reaction or false positive reaction in samples from areas with subclinical prevalence of brucellosis (7-14). To ensure efficient brucellosis disease prevention and control, a rapid and accurate identification method is required. In recent years, various studies have

\section{Corresponding author:}

Assistant Professor Dr. Seyed Mahmoud Amin Marashi, in Medical Bacteriology Department of Microbiology and Immunology Alborz University of medical sciences, Karaj, Iran.

Tel: +98-263-433-6007. Fax: +981132207918, Email: Parsmicrob2@gmail.com

Received: April 07, 2016, Accepted: June 14, 2016, Published: November 2016

iThenticate screening: June 03, 2016, English editing: August 16, 2016, Quality control: September 08, 2016

(C) 2016 The Authors. This is an open access article under the terms of the Creative Commons Attribution-NonCommercialNoDerivs License, which permits use and distribution in any medium, provided the original work is properly cited, the use is non-commercial and no modifications or adaptations are made. 
shown that polymerase chain reaction (PCR) can be used routinely to detect DNA from peripheral blood and other tissues as they are rapid, high specific and sensitive. Moreover, various PCR techniques, target genes and primer pairs have been used to detect Brucella spp. $(15,16)$. The most common molecular targets in clinical applications for the detection of Brucella spp, are the IS711 insertion element and the bcsp31 gene $(17,18)$. Because of the prevalence of brucellosis in Iran, a specific diagnostic method should be conventional for the control of Brucella in this population. The purpose of this study was to expand a molecular test that would be used for the develop detection of Brucella in a single reaction, with high sensitivity and specificity by targeting IS711 element.

\section{Material and Methods}

\subsection{Research design and setting}

The present study was conducted from 2015 to 2016 at the Ayatolla Rohani hospital in Babol, Iran. We used $B$. melitensis serotype 1 (strain 16M) and B. abortus B19 as the standard strain (provided by the Department of Bacterial Vaccines and Antigens Production, Pasteur Institute of Iran) and the standard strains of Escherichia coli ATCC 25922 as the negative control (provided by the Persian Type Culture Collection of Iranian Research), which were phylogenic related with Brucella spp. DNA from these strains were isolated using a purification kit (Roche Applied Sciences, Mannheim, Germany) in accordance with the manufacturer's instructions. The DNA pellet was suspended in $10 \mathrm{mMol} \mathrm{TE}$ buffer and stored at $-20^{\circ} \mathrm{C}$ until required for analysis. DNA concentration and purity were assessed by reading NanoDrop 2000c Spectrophotometer $A_{260}$ and $A_{280}$. To study the influence of DNA template from clinical blood specimens, about $3 \mathrm{ml}$ peripheral blood sample was collected and taken for PCR analysis. All samples were aliquot and stored at $-20^{\circ \mathrm{C}}$ until tested. DNA was extracted from whole blood $(200 \mu \mathrm{l})$ with the QIAamp DNA Blood Mini Kit (Qiagen) in accordance with the manufacturer's instructions.

\subsection{Oligonucleotide primers}

In this study, we designed four novel primers by extensive literature and nucleotide sequence searches in the NCBI databases. The DNA was then subjected to PCR detection by primers specific to the IS711 genes and this gene is unique within Brucella spp. Primer pairs were studied, using the bioinformatics software AlleleID 6. The DNA sequence comparisons with GenBank database were searched and assessed for species or genus assignment using BLAST. A pair of primers EFQ1 was previously reported to amplicon of 251 base pair (bp) that spans a region of the B. melitensis genome (GenBank accession number AE009555) and the IS711insertion element (19). We have proved that this pair of primers is specific for the genus Brucella spp, because when we used these primers for nonBrucella species templates, they did not amplify any PCR product. Primer sequences used in this study are shown in Table 1.

Table 1. List of oligonucleotide primers used in this study

\begin{tabular}{|l|l|l|l|}
\hline $\begin{array}{l}\text { Primer } \\
\text { name }\end{array}$ & Forward $\left(5^{\prime} \rightarrow 3^{\prime}\right)$ & Reverse $\left(5^{\prime} \rightarrow 3^{\prime}\right)$ & $\begin{array}{l}\text { Size of amplicon } \\
(\mathrm{bp})\end{array}$ \\
\hline Nes 2 & CAAGCCGCTCATATTCAC & CCAAGGTCAATCCAACAC & 547 \\
\hline Nes 1 & CGCTCGCTGCCATACTTGC & CGCTCGCTGCCATACTTGC & 291 \\
\hline Det & AGAATAATCCACAGAAGGTAGAG & ATCCAAGGTCAATCCAACAC & 403 \\
\hline Mar & GCATTCAATCTGATGGCGTTCC & GATCACTTAAGGGCCTTCATTGC & 127 \\
\hline EFQ1 & TGTTTCGGCTCAGAATAATCCA & GCATGCGCTATGATCTGGTTAC & 251 \\
\hline
\end{tabular}

\subsection{Optimization of DNA amplification}

Suitable adjustments were set up in the concentration of critical reagents such as primer, $\mathrm{MgCl}_{2}$ and template DNA, also annealing temperature of thermocycling to obtain optimal amplification of targeted genes of standard strains, for several times. The PCR was performed in $25 \mu \mathrm{l}$ volumes that contained $2.5 \mu \mathrm{l}$ of $10 \mathrm{X}$ buffer, $0.5 \mathrm{mmol} / \mathrm{L}$ $\mathrm{MgCl}_{2}, 0.3 \mathrm{mmol} / \mathrm{L}$ dNTPs (Fermentas, GmbH, Germany), $0.5 \mathrm{pmol} / \mathrm{L}$ from each primer, 0.2 unit of Taq DNA polymerase enzyme, and $1 \mu 1$ extracted DNA (For blood sample we used $5 \mu 1$ of extracted DNA). PCRs were run using the following steps: a primary denaturation for four minutes at $94^{\circ} \mathrm{C}$ followed by 30 cycles of denaturation at $94{ }^{\circ} \mathrm{C}$ for 1 minute, annealing gradient temperature ranging from $50{ }^{\circ} \mathrm{C}$ to $70{ }^{\circ} \mathrm{C}$ for 1 minute and extension at $72{ }^{\circ} \mathrm{C}$ for two minutes. At the end, one cycle for completion of the final extension was at $72{ }^{\circ} \mathrm{C}$ for 12 minutes. Then, $10 \mu \mathrm{L}$ of the PCR was subjected to electrophoresis on $1.5 \%$ agarose gel (Cinagene Co, Iran) stained by $0.5 \mu \mathrm{g}$ of ethidium bromide/ml (Sigma, Germany) and the results were evaluated in the presence of $100 \mathrm{bp}$ DNA size marker (Fermentas Co, Ukraine), visualized under UV transilluminator. Finally, amplification products were sequenced by Macrogen Inc, Seoul, Korea. 


\subsection{Sensitivity of PCR based on genomic DNA concentration}

Comparison of sensitivity between five pairs of primers assay (Nes2, Nes1, Det, Mar and EFQ1) was evaluated by using serial dilutions of DNA template $\left(10^{-1}-10^{-4}\right)$ of B. melitensis and (final protocol and the optimized thermal profile), the PCR reaction was performed. Then sensitivity for each pair of primers was determined by detection of limitations for the number of bacteria in PCR.

\section{Results}

Our set of five PCR primers could be useful to amplify the DNAs from the genus Brucella. Although the best range of concentration of all primers was 10-15 pmol after standardizing on individual PCRs with target genes, but for solution, $10 \mathrm{pmol}$ primers were used in all experiments. Also, the concentration of magnesium chloride was varied from 0.5 to $3 \mathrm{mM}$. The optimum chloride magnesium concentration for the assay was determined to be $2 \mathrm{mM}$. As a result, at the low concentrations there were no detectable PCR fragments, while at high chloride magnesium concentration there were amplified nonspecific PCR products so, gradient annealing temperature at $60{ }^{\circ} \mathrm{C}$ was found to be optimum. It should be mentioned that when PCR was used, the ability of the primers were such that in the temperature range $50-70^{\circ} \mathrm{C}$ as the annealing temperature, a single sharp band was obtained (Figure 1). The result showed that, the developed PCR assay had complete specificity, for not only was any amplified product observed with DNA of closely related organisms, but also could be selectively amplifying the targeted genes when performed on the clinical isolates (Figure 2). The comparison of the sensitivity of primers showed that the most sensitive primers were MAR amplified (12 fg). EFQ1, Nes2 (6 fg) and Nes1, Det (4 fg), respectively, of purified genomic DNA from B. melitensis (Figure 3).

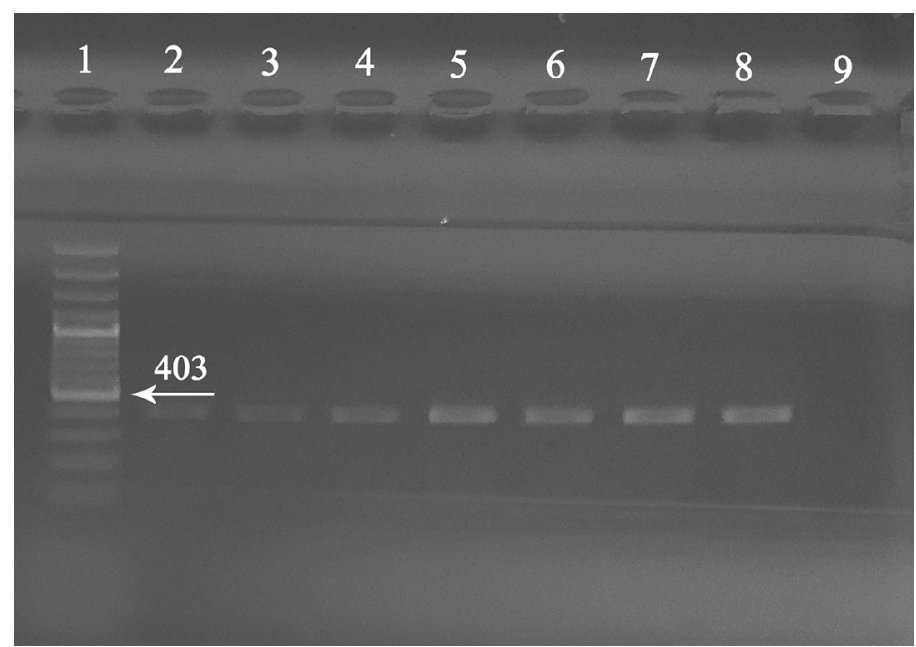

Figure 1. Agarose gel electrophoresis of PCR amplified products. Lane 1: DNA size marker (100 bp DNA ladder), Lanes 2-8: B. melitensis amplification product, Lane 9: negative control.

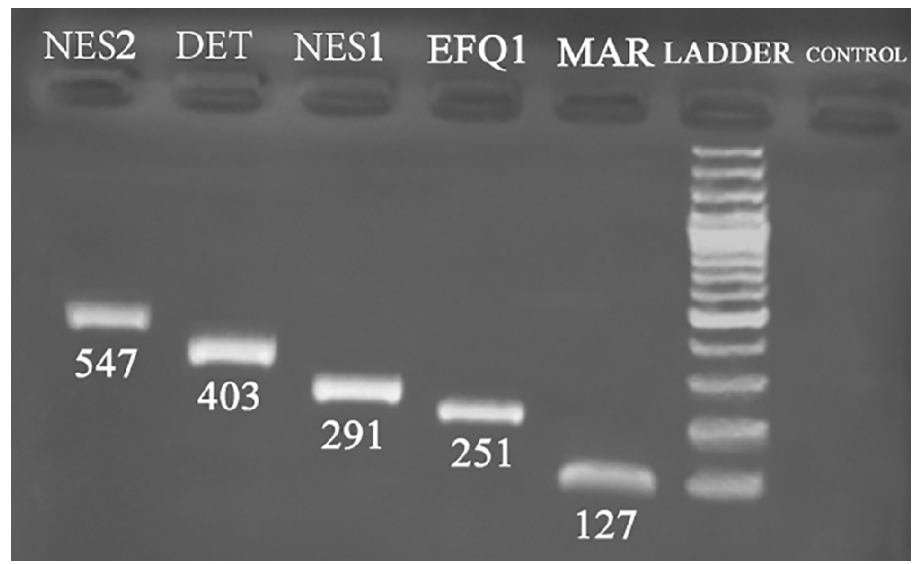

Figure 2. Specificity of five pairs of primers assays (Nes2, DET, Nes1, EFQ1 and Mar). Lanes1-5: positive control of DNA template of B. melitensis, lane 6: DNA size marker (100 bp DNA ladder), lane 7: negative control. 


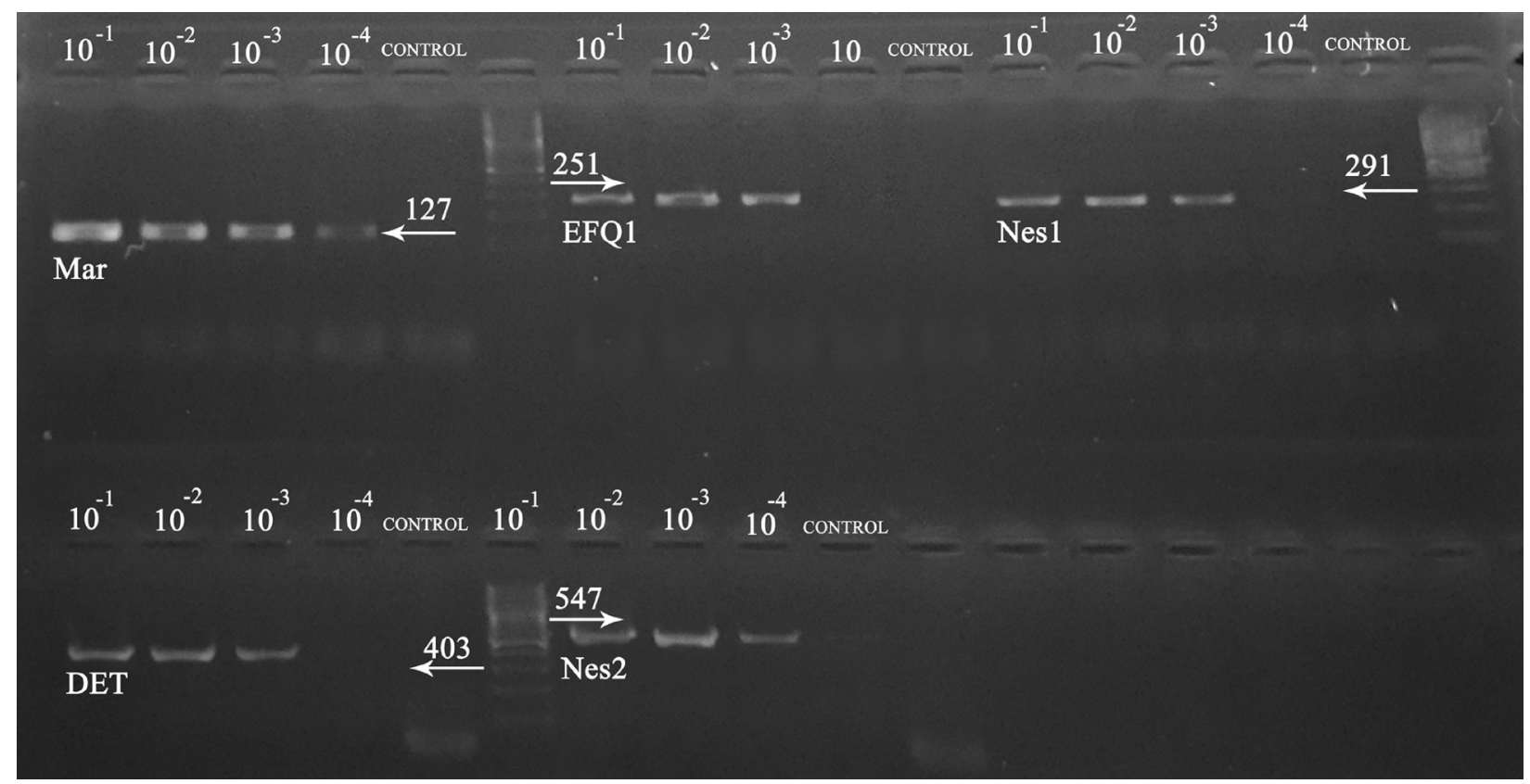

Figure 3. Sensitivity of five pairs of primers assay (Mar, EFQ1, Nes1, DET, and Nes2) with serial dilutions of DNA template of B. melitensis (10-1-10-4) respectively, control negative and DNA size marker (100 bp DNA ladder).

\section{Discussion}

Detecting Brucella species from infected animals and humans has been a public health concern for creating control and preventative policy in the region. Several PCR based methods are presented for Brucella diagnosis all over the world $(15,20)$. Based on our results, the single-stage PCR, using five pairs of primers could detect standard and native strains of Brucella Spp. It is important that a variety of concentrations of reaction components (concentrations of $\mathrm{MgCl}_{2}$, dNTP and Taq polymerase) be proportionate to obtain the highest efficiency. The concentration should be optimized, since primers may act differently. Also, finding denaturation temperature, denaturation duration, and the annealing temperature are important subjects which are valuable and time consuming and require expert personnel. In contrast with other studies $(20,21)$, our study showed difference in sensitivity because of protocol conditions such as concentrations of primers, $\mathrm{dNTPs}, \mathrm{MgCl}_{2}$, and Taq polymers. In the study by Da Costa et al, the specificity of primers on the 98 non-Brucella bacteria, mentioned that all organisms were negative for amplification of the BCSP31 gene (22). In this study the specificity of each primer pairs that were tested, the exact specific amplification was shown as the correct predicted product size. Moreover, the specificity of the primers has been tested against closely related bacterial species, and indicates that this assay is highly specific for Brucella. Some researches stated that during the DNA extraction from different tissues such as blood, some unknown inhibiting factors may be confounded on PCR product and could especially be affected on the sensitivity of it. $(23,24)$. Interestingly, these primers which were examined in this paper did not reduce the capability of the PCR to detect specific target genes of the Brucella.spp. Therefore it is suggested that these primer pairs can also be useful for the direct detection of Brucella species in tissue samples. Also, like other studies such as those conducted by Huber et al and Kazemi et al, this study showed that PCR was a sensitive and suitable method for detecting Brucella species $(25,26)$. More studies will be needed to improve the specificity and sensitivity of molecular methods before recommending routine laboratory detection.

\section{Conclusions}

In the recent study the PCR improved to detect Brucella simultaneously in a single reaction. The assay shows that the PCR method has high specificity and sensitivity. This method can be more useful than microbiological and serological tests and in addition, this aspect reduces the number of required tests. Therefore, we are recommending that the PCR can be used to test tissue and blood specimens as well as bacterial culture. 


\section{Acknowledgments:}

This article was extracted from a Ph.D. thesis at Babol University of Medical Sciences. We thank the University for funding this project with grant number 1978. The authors acknowledge the entire personnel of the Department of Infectious Diseases, Babol Medical University, Iran and the patients who participated in this study.

\section{Conflict of Interest:}

There is no conflict of interest to be declared.

Authors' contributions:

All authors contributed to this project and article equally. All authors read and approved the final manuscript.

\section{References:}

1) Christopher S, Umapathy BL, Ravikumar KL. Brucellosis: review on the recent trends in pathogenicity and laboratory diagnosis. J Lab Physicians. 2010; 2(2): 55-60. doi: 10.4103/0974-2727.72149. PMID: 21346896, PMCID: PMC3040083.

2) De Santis R, Ciammaruconi A, Faggioni G, Fillo S, Gentile B, Di Giannatale E, et al. High throughput MLVA-16 typing for Brucella based on the microfluidics technology. BMC Microbiol. 2011; 11: 60. doi: 10.1186/1471-2180-11-60. PMID: 21435217, PMCID: PMC3078841.

3) Franco MP, Mulder M, Gilman RH, Smits HL. Human brucellosis. Lancet Infect Dis. 2007; 7(12): 775-86. doi: 10.1016/S1473-3099(07)70286-4. PMID: 18045560.

4) Scholz HC, Kämpfer P, Cloeckaert A. Brucella: relationship to other Alphaproteobacteria, current taxonomy and the emergence of new species. Brucella: Molecular Microbiology and Genomics. $2012 ; 1$.

5) Araj GF. Update on laboratory diagnosis of human brucellosis. Int J Antimicrob Agents. 2010; 36(1): 12-7. doi: 10.1016/j.ijantimicag.2010.06.014. PMID: 20692128.

6) Alamian S, Aghaiipoor K, Salehi T, Esmaelizad M, Fasaei B, Etemadi A. Detection of Brucella melitensis and Brucella abortus strains using a single-stage PCR method. Arch Razi Inst. 2015; 70(1): 51-5.

7) Owlia MB, Danesh-Ardakani M. Frequency of sacroiliitis among patients with low back pain. Electron Physician. 2016; 8(3): 2094-100. doi: 10.19082/2094. PMID: 27123217, PMCID: PMC4844474.

8) Pappas G. The changing Brucella ecology: novel reservoirs, new threats. Int J Antimicrob Agents. 2010; 36(1): 8-11. doi: 10.1016/j.ijantimicag.2010.06.013. PMID: 20696557.

9) Al Dahouk S, Nockler K. Implications of laboratory diagnosis on brucellosis therapy. Expert Rev Anti Infect Ther. 2011; 9(7): 833-45. doi: 10.1586/eri.11.55. PMID: 21810055.

10) Roushan MR, Amiri MJ. Update on childhood brucellosis. Recent Pat Antiinfect Drug Discov. 2013; 8(1): 42-6. doi: 10.2174/1574891X11308010008. PMID: 22812616.

11) Hasanjani Roushan MR, Ebrahimpour S, Moulana Z. Different Clinical Presentations of Brucellosis. Jundishapur J Microbiol. 2016; 9(4): 33765. doi: 10.5812/jjm.33765. PMID: 27284398, PMCID: PMC4897599.

12) Nielsen K, Yu W. Serological diagnosis of brucellosis. Prilozi. 2010; 31(1): 65-89. PMID: 20703184.

13) Pabuccuoglu O, Ecemis T, El S, Coskun A, Akcali S, Sanlidag T. Evaluation of serological tests for diagnosis of brucellosis. Jpn J Infect Dis. 2011; 64(4): 272-6. PMID: 21788700.

14) Hasanjani Roushan MR, Moulana Z, Mohseni Afshar Z, Ebrahimpour S. Risk Factors for Relapse of Human Brucellosis. Glob J Health Sci. 2016; 8(7): 53370. doi: 10.5539/gjhs.v8n7p77. PMID: 26925907.

15) Navarro E, Escribano J, Fernandez J, Solera J. Comparison of three different PCR methods for detection of Brucella spp in human blood samples. FEMS Immunol Med Microbiol. 2002; 34(2): 147-51. PMID: 12381466.

16) Cloeckaert A, Grayon M, Grepinet O. An IS711 Element Downstream of thebp26 Gene Is a Specific Marker of Brucella spp. Isolated from Marine Mammals. Clin diagnos lab immunol. 2000; 7(5): 835-9. PMID: 10973465, PMCID: PMC95966.

17) Pérez-Sancho M, García-Seco T, Arrogante L, García N, Martinez I, Diez-Guerrier A, et al. Development and evaluation of an IS711-based loop mediated isothermal amplification method (LAMP) for detection of Brucella spp. on clinical samples. Res vet sci. 2013; 95(2): 489-94. doi: 10.1016/j.rvsc.2013.05.002. PMID: 23714043.

18) Bounaadja L, Albert D, Chénais B, Hénault S, Zygmunt MS, Poliak S, et al. Real-time PCR for identification of Brucella spp.: a comparative study of IS711, bcsp31 and per target genes. Vet Microbiol. 2009; 137(1-2): 156-64. doi: 10.1016/j.vetmic.2008.12.023. PMID: 19200666. 
19) Navarro E, Segura JC, Castaño MJ, Solera J. Use of real-time quantitative polymerase chain reaction to monitor the evolution of Brucella melitensis DNA load during therapy and post-therapy follow-up in patients with brucellosis. Clin infect dis. 2006; 42(9): 1266-73. doi: 10.1086/503035. PMID: 16586386.

20) Truong QL, Yoon BI, Hahn TW. Development of a multiplex PCR to identify Salmonella, Leptospira and Brucella species in tissue samples. Korean J Vet Res. 2012; 52(2): 75-82.

21) Kumar S, Tuteja U, Sarika K, Singh D, Kumar A, Kumar O. Rapid multiplex PCR assay for the simultaneous detection of the Brucella Genus, B. abortus, B. melitensis, and B. suis. J Microbiol Biotechnol. 2011; 21(1): 89-92. PMID: 21301197.

22) Da Costa M, Guillou JP, Garin-Bastuji B, Thiébaud M, Dubray G. Specificity of six gene sequences for the detection of the genus Brucella by DNA amplification. J Appl Bacteriol. 1996; 81(3): 267-75. PMID: 8810054 .

23) Hansen WL, Bruggeman CA, Wolffs PF. Pre-analytical sample treatment and DNA extraction protocols for the detection of bacterial pathogens from whole blood. Methods Mol Biol. 2013; 943: 81-90. doi: 10.1007/978-1-60327-353-4-4. PMID: 23104282.

24) Al Dahouk S, Sprague LD, Neubauer H. New developments in the diagnostic procedures for zoonotic brucellosis in humans. Rev Sci Tech. 2013; 32(1): 177-88. PMID: 23837375.

25) Buyukcangaz E, Sen A, Carli K, Kahya S. Comparison of direct culture versus PCR for the detection of Brucella in aborted fetuses of cattle and sheep in Turkey. Vet Rec. 2011; 168(16): 430. doi: 10.1136/vr.c7003. PMID: 21493448.

26) Huber B, Scholz HC, Lucero N, Busse HJ. Development of a PCR assay for typing and subtyping of Brucella species. Int J Med Microbiol. 2009; 299(8): 563-73. doi: 10.1016/j.jimm.2009.05.002. PMID: 19560966. 